УДК 65.011 .47

Pererva P. G.

Doctor of Economics, Professor, Dean of the economic faculty National Technical University "Kharkiv Polytechnic Institute" (Kharkiv, Ukraine); Dr. hab, Professor, Higher School of Labour Safety Management - WSZOP, Poland; e-mail:pgpererva@gmail.com

Kosenko A. P.

Doctor of Economics, Professor of the Department of Department of Economics and Marketing National Technical University "Kharkiv Polytechnic Institute” (Kharkiv,Ukraine); e-mail:kosenkoalexandra1@gmail.com

Kobielieva T. A.

Candidate of Economic Sciences, Associate Professor of Department of Business Administration and Personnel Management, National Technical University “Kharkiv Polytechnic Institute”, Ukraine; e-mail:tanja.kobeleva@gmail.com

Tkachev M. M.

Candidate of Economic Sciences, Associate Professor of Department of Law, National Technical University "Kharkiv Polytechnic Institute”, Ukraine; e-mail:tkachovmaksim85@gmail.com

Tkacheva N.P.

Candidate of Economic Sciences, Associate Professor of Department of Economics and Marketing National Technical University "Kharkiv Polytechnic Institute” , Ukraine; e-mail:tkachovanadegda@gmail.com

\title{
FINANCIAL AND TECHNOLOGICAL LEVERAGE IN THE SYSTEM OF ECONOMIC EVALUATION OF INNOVATIVE TECHNOLOGIES
}

Abstract. The article examines the conceptual, theoretical and methodological guidelines for economic evaluation of innovative technologies through financial and technological leverage. The concept of financial-technological linkage was developed with the aim of establishing a relationship between technological efficiency and effectiveness of operational and financial activities of the enterprise. The authors have developed measurement technology and the use of technological linkage as a tool for assessing commercial potential of new technologies, which allows establishing a link between technological efficiency and effectiveness of operational and financial activities of the engineering enterprise.

It is proved that the concept of technological linkage explains how the creation of new technologies can raise the value of the business, exceeding significantly the value of the underlying technological innovations taken in isolation. In addition, there is a real possibility of effective monitoring of the economic impact (need, usage, efficiency) from the use of технологічнбої development, the exclusive rights which are at the disposal of the enterprise.

Determined that the level of commercial potential of intellectual technology is not limited only to the influence of technological leverage. The potential power can be represented as a dependence of the level of commercial potential of several very important factors that act in parallel. They proposed to include the following, the most important components of the level of commercial potential of innovative technology: the lever of the early stages of the life cycle of an innovative product; the lever of the developer technological innovations; financial leverage.

The effect of financial and technological leverage depends on innovation activity and innovation capacity of the enterprise-the developer of a technological product. Its value is usually higher for industries with higher technological level of production, which is very typical for innovative enterprises.

Keywords: Finance, technology, technological leverage, innovation, cost, effect, enterprise JEL Classification: G32, O32, O33

Formulas: 10; fig.: 1; tabl.: 0; bibl.: 19 
Перерва П. $Г$.

д.е.н., професор, декан економічного факультету, національний технічний університет «Харківський політехнічний інститут», Україна; професор Вищої школи управління охороною праці, Польща; e-mail: pgpererva@gmail.com

Косенко О. П.

д.е.н., професор кафедри економіки і маркетингу національний технічний університет «Харківський політехнічний інститут», Украӥна; e-mail:kosenkoalexandra1@gmail.com

Кобелєва Т. $\boldsymbol{O}$.

к.е.н., доиент кафедри організації виробництва і управління персоналом національний технічний університет «Харківський політехнічний інститут»,

Україна; e-mail:tanja.kobeleva@gmail.com

Ткачова Н. П.

к.е.н., доцент кафедри економіки і маркетингу національний технічний університет «Харківський політехнічний інститут», Україна; e-mail:tkachovanadegda@gmail.com

Ткачов М. М.

к.е.н., доцент кафедри права національний технічний університет «Харківський політехнічний інститут», Украӥна; e-mail:tkachovmaksim85@gmail.com

\section{ФІНАНСОВО-ТЕХНОЛОГІЧНИЙ ВАЖІЛЬ В СИСТЕМІ ЕКОНОМІЧНОЇ ОЦІНКИ ІННОВАЦІЙНИХ ТЕХНОЛОГІЙ}

Анотація. В статті розглянуто концептуальні теоретико-методичні положення економічної оцінки інноваційних технологій на засадах фінансово-технологічного важеля. Обгрунтовано, що концепція технологічного важеля пояснює, яким чином створення нової технології може підняти вартість бізнесу, перевищуючи в рази цінність базової технологічної інновації, взятої ізольовано. Крім того, з'являється реальна можливість ефективного моніторингу економічної віддачі (потреби, використання, ефективності) від використання технологічної розробки, виключні права на яку знаходяться в розпорядженні даного підприємства.

Ключові слова: фінанси, технологія, технологічний важіль, інновації, витрати, ефект, підприємство

Формул: 10; рис.: 1; табл.: 0; бібл.: 19

Перерва П. Г.

д.э.н., профессор, декан экономического факультета, национальный технический университет «Харьковский политехнический институт», Украина;

профессор Высшей школы управления охраной труда, Польша; e-mail:pgpererva@gтаil.com

Косенко А. П.

д.э.н., профессор кафедры экономики и маркетинга национальный технический университет «Харьковский политехнический институт», Украина;

e-mail:kosenkoalexandra1@gmail.com

кобелева Т. А.

к.э.н., дочент кафедры организации производства и управления персоналом национальный технический университет "Харьковский политехнический институт»,

Украина; e-mail:tanja.kobeleva@gmail.com

Ткачева Н. П.

к.э.н., доцент кафедры экономики и маркетинга национальный технический университет «Харьковский политехнический институт», Украина; e-mail:tkachovanadegda@gmail.com

Ткачев М. М.

к.э.н., дочент кафедры права национальный технический университет «Харьковский политехнический институт»,Украина; e-mail:tkachovmaksim85@gmail.com 


\section{ФИНАНСОВО-ТЕХНОЛОГИЧЕСКИЙ РЫЧАГ В СИСТЕМЕ ЭКОНОМИЧЕСКОЙ ОЦЕНКИ ИННОВАЦИОННЫХ ТЕХНОЛОГИЙ}

Аннотация. В статье рассмотрены концептуальные теоретико-методические положения экономической оценки инновационных технологий на основе финансовотехнологического рычага. Обосновано, что концепция технологического рычага объясняет, каким образом создание новой технологии может поднять стоимость бизнеса, превышая в разы ценность базовой технологической инновации, взятой изолированно. Кроме того, появляется реальная возможность эффективного мониторинга экономической отдачи (потребности, использование, эффективность) от использования технологической разработки, исключительные права на которую находятся в распоряжении данного предприятия.

Ключевые слова: финансы, технология, технологический рычаг, инновации, затраты, эффект, предприятие

Формул: 10; рис.: 1; табл.: 0; библ.: 19

Introduction. The concept of «linkage» is widely used in various natural Sciences and refers to a device or mechanism that allows increasing the impact on a particular object. For example, in the financial management as such a mechanism acts as a constant component in the total costs of the enterprise. In the context of this study the concept of technological lever will display the rate of change of the increment of capital of the company in relation to the level of change it costs of intellectual and technological development. If a positive value of technology leverage is possible to conclude about the level of innovative receptivity of enterprise-developer of technological innovations, skills and abilities not only to create a progressive innovative technologies (IT), but to effectively use (commercialization) in his own intellectual development.

Analysis of the research and the problem statement. A significant contribution to the development of theoretical and methodical provisions financial provision and commercialization of technological innovations made in the scientific works of Zhehus O.V. [1], Gladenko I.V. [2], Kosenko A.P. [3-5], Kotsiski D. [6, 7], Pererva P.G. [8, 9], Platonov V.V. [10], Poberezhna N.M. [11], Pogorelov I.M. [12], Rogova O.M. [13], Savenkova O.N. [14], Starostina A.A. [15] and others [16-19].

The concept of financial and technological leverage has been developed by a number of scholars [3, 6, 8, 10, 13] with the aim of establishing a relationship between technological efficiency and effectiveness of operational and financial activities of the enterprise. In $[10,13]$ technological lever is defined as a measure of the ability of innovative enterprises to disseminate knowledge, technology, application know-how (that is, to implement the transfer of technology) obtained in the process of creating a basic IT $\left(I T_{\text {bas }}\right)$, many products for end users.

However, an extremely important task is the development of the concept of technological linkage as a tool for assessing commercial potential of technologies that allows to establish a link between technological efficiency and effectiveness of operational and financial activities of the engineering enterprise.

Results of Research. Analytical model of technological leverage can be expressed using the cost approach of accounting, the carrying value of tangible assets used in the following way:

$$
T L=\sum_{i=1}^{N} \frac{C_{i}+C_{\text {bas }}}{C_{\text {bas }}},
$$

where $T L$ - the technological arm; $N$ - is the number of new areas and the use of basic intellectual and innovative technology ( $I T_{\text {bas }}$ ) in products and technologies; $C_{\text {bas }}$ - costs (the cost of tangible assets) related to the development $I T_{b a s} ; C_{i}$ - valuation of material expenses for the development of the $i$-th product or technology created with the use of $I T_{\text {bas }}$. 
However, we are aware of the fact that the actual costs associated with the creation of new spheres and directions of use of the basic intellectual-innovative technologies in products and technologies in the General case can be considerably higher than those indicated in the formula (1). The fact that research and innovation activities always involve risk of obtaining a negative result, that is, the economic result a positive character (reproduced in the model (1) is achieved with larger total costs $C_{\Sigma}$. This package can be played like this:

$$
C_{\Sigma}=C_{\Sigma} P_{\text {поз }}+C_{\Sigma} P_{\text {нег }}
$$

where $P_{\text {pos }_{i}}, P_{\text {neg }_{i}}$ - is the probability, respectively, a positive or negative result from the use of and development costs $C_{\Sigma_{i}}$, the direction of $i$-th scope of use $I T_{\text {bas }}$.

Due to the fact that the probabilities $P_{\text {pos }_{i}}$ and $P_{\text {neg }_{i}}$ constitute the complete group of incompatible events (as each $i$-th direction, and across product and technology platform as a whole), then the fair will be the following equality: $\left(P_{\text {pos }_{i}}+P_{\text {neg }_{i}}=1\right)$ or $\left(P_{\text {pos }}+P_{\text {neg }}=1\right)$. Taking this into account, formula (2) takes the following form:

$$
\begin{array}{ll} 
& C_{\Sigma}=C_{\text {pos }}+C_{\text {neg }}, \\
\text { hence: } & C_{i}=C_{\text {pos }}=\left(C_{\Sigma}-C_{\text {neg }}\right) .
\end{array}
$$

On this basis, determine the amount of total costs $C_{\Sigma}$ that are associated with both positive and negative nature of their use in creating $i$-th directions or areas of application $I T_{\text {bas }}$. If the actual value of costs of the enterprise will be more optimally required cost $C_{\text {fact }}>C_{\text {opt }}$, the total negative costs of the enterprise for the creation of product and technological platforms will be:

$$
C_{\text {neg }}=\left(C_{\text {fact }}-C_{\text {opt }}\right)=R_{c}\left(N_{\Sigma}-N_{\text {pos }}\right) \text {, }
$$

where $N_{\Sigma}$ - is the total number of attempts of development $i$-th directions or areas of application $I T_{\text {bas }}$ (both positive and negative), which carried out the enterprise, that is $N_{\Sigma}=N_{\text {pos }}+$ $N_{\text {neg. }}$. Of course, these opportunities at the enterprise not always, and that is each of them should be economically justified. If the company will not appropriate the funds, its total potential loss (loss of profits) from the use of $i$-th direction $I T_{\text {bas }}$ will be $R_{\text {los }}\left(N_{\Sigma}-N_{\text {pos }}\right)$, where: $R_{c}, R_{\text {los }}-$ respectively, the average costs of the enterprise the creation of one of the directions of use $I T_{b a s}$ and the average economic losses (lost profits) in the event of his absence.

In advance it is impossible to call the number $i$-th directions $I T_{\text {bas }}$, which will be disbursed by the enterprise, proceeding from its capabilities, but with the known distribution function of development areas $I T_{\text {bas }}$ possible to determine the expected costs for a given number of directions of use $I T_{b a s}$ in the form of economic-mathematical models, taking the integral costs for each direction multiplied by the appropriate probability $f\left(N_{\text {pos }}\right)$ :

$$
R=R_{c} \int_{0}^{N}\left(N_{\Sigma}-N_{p o s}\right) f\left(N_{p o s}\right) d N_{p o s}+R_{\text {los }} \int_{N}^{\infty}\left(N_{\Sigma}-N_{p o s}\right) f\left(N_{p o s}\right) d N_{p o s}
$$

The task is to find such a number developed by the company and-x directions $I T_{b a s}$ in which the function of total costs and losses $\mathrm{R}$ will be the smallest. This is a common problem of differential calculus: $R=\min$, if $d R / d N_{\text {поз }}=0$. Taking the derivative of expressions (3) and after simple transformations, we obtain the following equation: 


$$
\frac{\int_{0}^{N} f\left(N_{p o s}\right) d N_{p o s}}{\int_{N}^{\infty} f\left(N_{p o s}\right) d N_{p o s}}=\frac{R_{l o s}}{R_{c}} .
$$

The integral in the numerator of the left side of the expression (4) reflects the probability that the enterprise successfully (without negative consequences) will invest their money on creating $i$-th directions of use $I T_{b a s}$, that is, it is the probability value $P_{\text {pos }_{i}}$. The integral in the denominator of the left side of the expression (4) reflects the probability that the enterprise failed (with negative consequences) will invest their money on creating $i$-th directions of use $I T_{b a s}$, that is, the probability of the opposite event $1-P_{\text {pos }_{i}}$. Substitute these values into the expression (4) and solve it on $P_{\text {pos }_{i}}: \quad \frac{P_{\text {pos }}}{1-P_{\text {pos }}}=\frac{R_{\text {los }}}{R_{c}}$, from this expression:

$$
P_{p o s}=\frac{R_{l o s}}{R_{c}+R_{l o s}}
$$

The obtained expression allows to more accurately determine the probability of a positive return on investment in the creation of product and technology platform steam enterprise on the basis of $I T_{\text {bas }}$, has more rigorous economic justification and excludes the elements of arbitrariness and subjectivity when making economic decisions in industry consumption $I T_{\text {bas }}$.

The presence of technological leverage in the enterprise, based on the logic of formula (1) can be defined only if the value of the $T L$ in the formula (1) will be more than two $(T L>2)$. Otherwise, create $I T_{\text {bas }}$ not allow to create anything significant because the obtained results do not exceed the cost of creating the most $I T_{\text {bas }}$. We conclude that the concept of technological linkage explains how the creation of new IT can raise the value of the business, exceeding significantly the value $I T_{\text {bas }}$ taken in isolation. In addition, there is a real possibility of effective monitoring of the economic impact (demand, usage, applicability) of a particular IT, the rights to which are at the disposal of the enterprise, its impact on financial management system.

In this regard it should be noted that even before developed by the enterprise new areas and directions of use of the basic $I T_{\text {bas }}$ will be materialized in new instruments of labor or commodities (namely, then there will be real changes in the cost structure material assets and capital of the company), the technological arm $I T_{\text {bas }}$ will have an indirect effect on these assets. This is because when you create $I T_{b a s}$ and appearance with its use of the new developments and grow the intangible assets of the company, which primarily should include new knowledge, research and production experience, know-how, etc., which accordingly promotes the growth of the market value of the company. The presence of this factor helps to reduce the amount of investment in new development because it uses the already obtained results of investing in $I T_{\text {bas }}$. This allows to conclude that the impact of technological leverage will be directly proportional to the activity of the enterprise in two ways:

- first, the use of basic development $I T_{\text {bas }}$ to generate new intellectual products;

- secondly, in the system of internal and external technology transfer.

The economic essence of technological leverage in the developer of IT and its user clearly shown in Fig.1.

Level of commercial potential of intellectual technology $(L K P)$ is not limited to indicator (1), that is only technological lever. As the results of earlier studies [3, 16, 18, 19], the formation of the commercial potential of intellectual technology is influenced by not only technological arm TL. 
The potential power can be represented as a dependence of $L K P$ from a few very important factors that act in parallel. They proposed to include the following, as we think, the most important components of the $L K P$ : $T L>2$;

a) technological arm, the force of which is determined by the dependence (1) and condition

b) the lever for the early stages of the life cycle of an innovative product $-L E$, which occurs at the stage of market development for new products and supported by its originality, a high level of consumer properties and, consequently, a higher price, that is enforced price lever (price leverage IT).

In addition, the higher prices the company is a developer can install on their products and at the stage of monopoly presence in the market this $I T_{b a s}$ (the period of patent protection, exclusive licenses, etc.) and result in a higher profit margin (in addition to this enterprise at this stage to use $I T_{\text {bas }}$ for the manufacture of more advanced products in this period no one has the right).

Lever early stages of the life cycle of intellectual and innovative product $L E$ (price leverage IT) shows how many times the rate of change of sales prices exceeds the rate of change of the net profit calculated according to the formula:

$$
L E=\frac{P_{\text {sal }}}{P S}=\frac{P S+C_{\mathrm{var}}+C_{\text {const }}}{P S}=1+\frac{C_{\mathrm{var}}}{P S}+\frac{C_{\text {const }}}{P S},
$$

where $P_{s a l}$ - sales price of intellectually-innovative products, created using $I T_{b a s} ; P S-$ profit from sales; $C_{v a r}$ - variable costs in the unit cost of intellectual and innovative products; $C_{\text {const }}$ - fixed costs in product costs;

c) operating leverage (operating leverage natural) - OL - is closely associated with the lever for the early stages of the product life cycle and shows how many times the rate of change of net profit exceeds the rate of change of revenue. Progressive $I T_{b a s}$, as a rule, is confirmed by growing volumes of production and marketing of technological products $N_{p r}$. For effective $I T$ value $N_{p r}$., as a rule, more units, that is, when the increase of revenues (prices) by $1 \%$ profit will increase by a greater amount. Calculation of operating leverage of $O L$ with respect to intellectual innovation of products should be determined according to the formula:

$$
O L=\frac{N_{p r}-C_{\mathrm{var}}}{P S}=\frac{\left(P S+C_{\mathrm{var}}+C_{\text {const }}\right)-C_{\mathrm{var}}}{P S}=1+\frac{C_{\text {const }}}{P S} .
$$

d) the lever of the developer $I T_{\text {bas }}(L D)$ - plays receiving $I T_{\text {bas }}$ in the development of new knowledge, original information, research and production experience, know-how and the like, which can be used in the production of new or improvement of existing intellectual-innovative products and technologies. This can significantly affect the volume of investments in development that would be otherwise much more. Arm of the developer $I T_{\text {bas }}-L D$ - can be determined on the basis of the classical theory of economic efficiency: as all of the $j$-th of the results obtained (this is the total amount of all receipts in the budget of the developer from the sale $I T_{b a s}$ and all development on their basis $\sum_{j=1}^{J} E_{j}^{b u d}$ ) to the total costs (total costs of creation and promotion of all $j-$ th development on the basis of basic intellectual technologies $I T_{\text {bas }}$, including the base costs for the creation and promotion of $I T_{b a s}-\sum_{j=1}^{J} C_{j}^{I T} \quad$ ).

$$
L D=\sum_{j=1}^{J} E_{j}^{b u d} / \sum_{j=1}^{J} C_{j}^{I T}
$$




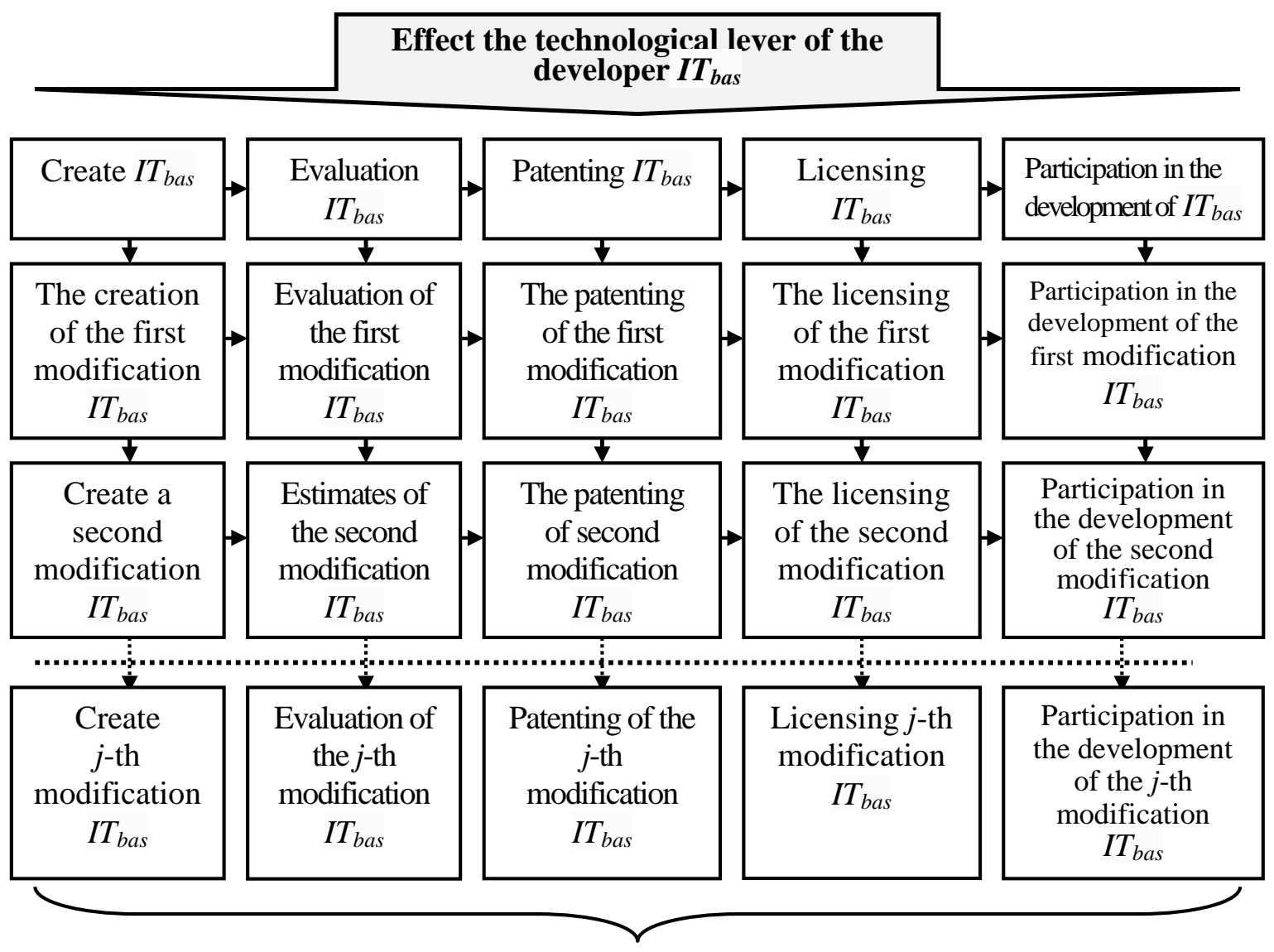

Product and technological platform based on ITbas in technology developer

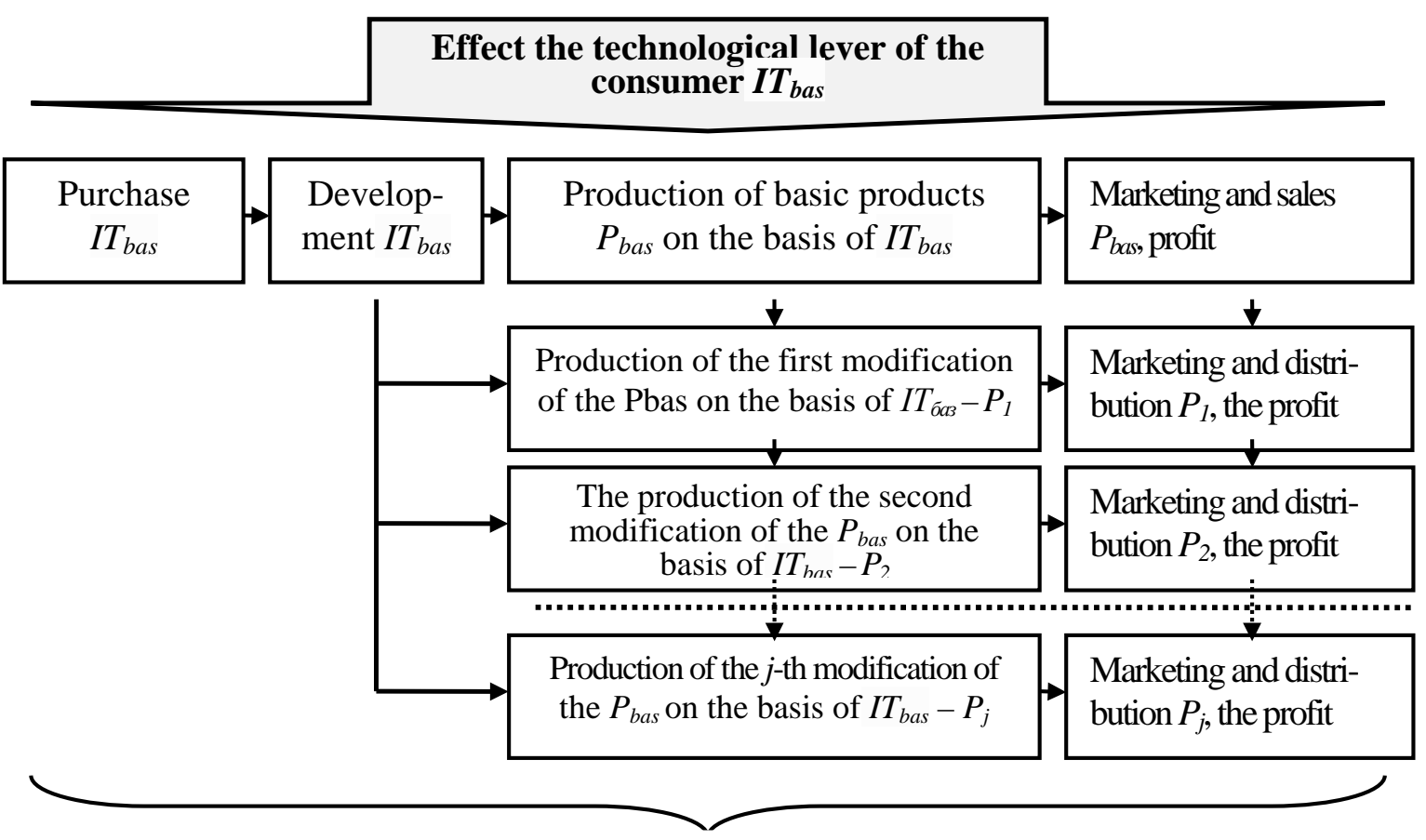

Product and technological platform based on ITbas in technology consumer

Figure 1. The economic essence of technological lever of the developer and the consumer of IT Source: compiled by the authors based on own researches

e) the strength of the commercial potential $I T_{\text {bas }}$ can also be considered as some function of financial lever - FL (financial leverage $I T$ ), reflecting the ratio of debt of the enterprise to equity - 
$K_{b o r}$ enterprise to equity $K_{o w n}$, that is $F L=K_{b o r} / K_{\text {own }}$. The smaller the value of financial leverage of the $F L$, the more stable position of the enterprise. On the other hand, borrowed capital allows to increase the rate of return on equity, i.e. to get additional return on equity. The indicator reflecting the level of additional income with the use of borrowed capital determines the effect of financial leverage $\left(E_{F L}\right)$. In the traditional formulation this indicator is calculated by the following formula:

$$
E_{F L}=K_{b o r} \frac{\left(1-H_{t a x}\right)\left(R_{a s s}-C I\right)}{K_{o w n}}=F L\left(1-H_{t a x}\right) D
$$

where $H_{\text {tax }}$ - the income tax (in shares); $R_{\text {ass }}$ - return on assets (ratio of gross profit to the average cost of all assets); $C I$ - credit interest rate; $D$ - the differential (the difference between return on assets and interest rate for the loan).

Conclusions. "The leverage effect» depends on the innovation activity and innovation capacity of the enterprise-the developer of $I T$. The value of $E_{F L}$, tend to be higher for industries with higher technological level of production, which is very typical for innovative enterprises. This situation contributes to the strengthening of the mechanism of efficiency of use of borrowed funds. If the implementation of a concrete investment project for the commercialization of $I T_{\text {bas }}$ the investment of capital provides an economic return on assets $R_{\text {ass }}$ and assets covered by own capital investments and debt $K_{\text {own }}$ funds at an interest rate of $K_{\text {bor }}$, the return on equity $R_{\text {own }}$ defined as follows:

$$
R_{o w n}=R_{a s s}+\frac{K_{b o r}\left(1-H_{t a x}\right)\left(R_{a s s}-C I\right)}{K_{o w n}}=R_{a s s}+E_{F L} .
$$

From the formula (10) follows the obvious conclusion that if a positive value of the differential lever $\left(D=R_{\text {ass }}-H_{\text {tax }}\right)>0$ and a positive value for the «lever arm» $\left(F L=K_{\text {bor }} / K_{\text {own }}\right)>$ 0 , the profitability of own funds more economic return on assets $R_{\text {ass }}\left(R_{\text {own }}>R_{\text {ass }}\right)$.

\section{Література}

1. Перерва, П. Г. Науково-інноваційний потенціал України та сучасні проблеми його використання [Електронний ресурс] I П. Г. Перерва, О. http://archive.nbuv.gov.ua/portal/Natural/vcpi/TPtEV/2011_26/statiya/Pererva.pdf.

2. Перерва, П. Г. Моніторинг інноваційної діяльності: інтерпретація результатів [Текст] / П. Г. Перерва, І. В. Гладенко // Маркетинг і менеджмент інновацій. - 2010. - № 2. - С.108-116.

3. Косенко, О. П. Переваги та недоліки існуючих підходів до вартісної оцінки інтелектуальних технологій [Текст] / О. П. Косенко, М. М. Ткачов // Вісник Національного технічного університету "ХПІ". Серія: Технічний прогрес та ефективність виробництва. - 2014. - № 65. - С. 46-56.

4. Косенко, О. П. Кон’юнктура технологічного ринку: оцінка ризиків комерціалізації об’єктів інтелектуальної власності [Текст] / О. П. Косенко, Т. О. Кобєлєва, П. Г. Перерва // Вісник Національного технічного університету "ХПІ". Серія: Технічний прогрес та ефективність виробництва. - 2014. - № 33. - С. 76-87.

5. Косенко, О. П. Технологічний важіль як інструмент формування продуктово-технологічних платформ машинобудівних підприємств [Текст] / О. П. Косенко // Технологический аудит и резервы производства. - 2015. - № 3 (5). C. 4-11.

6. Экономическая оценка инновационного потенциала $[$ Текст] / А. П. Косенко и др. / под ред. П. Г. Перервы, Д. Коциски. - Харьков-Мишкольц, 2009. - 165 с.

7. Коциски, Д. Стратегічне управління виробничим потенціалом і підвищення конкурентоспроможності підприємства [Текст] / Д. Коциски, П. Г. Перерва, А. П. Косенко // Вестник НТУ "ХПИ" : Технічний прогрес та ефективність виробництва. - 2010. - Вип. 62. - С. 137-142.

8. Косенко, О. П. Оцінювання комерційної привабливості об'єктів інтелектуальної власності на основі технологічного важеля $[$ Текст] / О. П. Косенко, П. Г. Перерва // Торговельне підприємництво: механізм розвитку і фінансової підтримки : монографія / за ред. С. В. Князя. - Львів : Львівська політехніка, 2015. - Розд. 1.4.4. - С. 180-195.

9. Перерва, П. Г. Синергетичний ефект бенчмаркінгу конкурентних переваг [Текст] / П. Г.Перерва, Н. П. Ткачова // Маркетинг і менеджмент інновацій . - 2011. - № 4, Т. 1. - С. 55-66.

10. Интеллектуальные активы и инновации: проблемы оценки, учета и управления [Текст] / В. В. Платонов и др. ; под ред В. В. Платонова. - Санкт-Петербург : Изд-во ГОУ ВПО «Санкт-Петербургский государственный университет экономики и финансов», 2008. - 161 с.

11. Перерва, П. Г. Визначення ефективності використання виробничого потенціалу машинобудівного підприємства [Текст] / П. Г. Перерва, Н. М. Побережна // Маркетинг і менеджмент інновацій. - 2012. - № 2. - С. 191-198. 
13. Рогова, Е. М. Формирование и реализация механизмов технологического трансфера [Текст] : монография / Е. М. Рогова. - Санкт-Петербург : Изд-во Санкт-Петербургского гос. ун-та экономики и финансов, $2005 .-191$ с.

14. Перерва, П. Г. Анализ финансового состояния предприятия [Текст] / П. Г. Перерва, О. Н. Савенкова // Вісник Національного технічного університету "ХПІ". Тематичний випуск: Технічний прогрес та ефективність виробництва. 2002. - № 11-2. - C. 118-121.

15. Маркетинг [Текст] : підручник / А. О. Старостина та ін. ; за ред. А. О. Старостиної. - К. : Знання, 2009. - 1070 с.

16. Перерва, П. Г. Розвиток методів вартісної оцінки нематеріальних активів та об'єктів інтелектуальної власності [Текст] / П. Г. Перерва, О. П. Косенко, М. М. Ткачов // Научные труды ДонНту. Серия: экономическая. - 2014. - № 4. - С. 57-66.

17. Перерва, П. Г. Антикризовий моніторинг фінансово-економічних показників роботи машинобудівного підприємства [Текст] / П. Г. Перерва, В. Л. Товажнянський // Економіка розвитку. - 2010. - № 2 (54). - С. 46-50.

18. Трансфер технологий [Текст] : монография / П. Г. Перерва и др. ; под ред. П. Г. Перервы, Д. Коциски. Харьков-Мишкольц : НТУ «ХПИ», 2012. - 668 с.

19. Экономика и управление инновационной деятельностью [Текст] : учебник / П. Г. Перерва и др. ; под ред. П. Г. Перервы, Г. К. Вороновского, С. А. Меховича, Н. И. Погорелова. - Харьков : НТУ «ХПИ», 2009. - 1203 с.

\section{References}

1. Pererva, P. H. \& Zhehus, O. V. (2011). Naukovo- innovatsiinyi potentsial Ukrainy ta suchasni problemy yoho vykorystannia. Available at: http://archive.nbuv.gov.ua/portal/Natural/vcpi/TPtEV/2011_26/statiya/Pererva.pdf

2. Pererva, P. H., \& Hladenko, I. V. (2009). Monitorynh innovatsiinoi diialnosti: interpetatsiia rezultativ. Marketynh $i$ menedzhment innovatsii, 2, 108-116.

3. Kosenko O. P. \& Tkachov, M. M. (2014). Perevahy ta nedoliky isnuiuchykh pidkhodiv do vartisnoi otsinky intelektualnykh tekhnolohii. Visnyk Natsionalnoho tekhnichnoho universytetu «KHPI». Seriia: tekhnichnyi prohress ta efektyvnist vyrobnytstva, 65, 46-56.

4. Kosenko, O. P., Kobelieva, T. O. \& Pererva, P. H. (2014). Koniunktura tekhnolohichnoho rynku: otsinka ryzykiv komertsializatsiii obektiv intelektualnoi vlasnosti. Visnyk Natsionalnoho tekhnichnoho universytetu «KHPI». Seriia: tekhnichnyi prohress ta efektyvnist vyrobnytstva, 33, 76-87.

5. Kosenko, O. P. (2015). Tekhnolohichnyi vazhil yak unstrument formuvannia produktovo-tehnolohichnykh platform mashinobudivnykh pidpryiemstv. Tekhnolohicheskii audit i rezervy proizvodstva, 3(5), 4-11.

6. Pererva, P. H., \& Kotsysky, D. (Eds.). (2009). Ekonomicheskaia otsenka innovatsionnogo potentsiala. KharkovMishkolts.

7. Kotsysky, D., Pererva, P. H., \& Kosenko, A. P. (2010). Stratehichne upravlinnia vyrobnychym potentsialom i pidvyshchennia konkurentospromozhnosti pidpryiemstva. Visnyk Natsionalnoho tekhnichnoho universytetu «KHPI». Seriia: tekhnichnyi prohress ta efektyvnist vyrobnytstva, 62, 137-142.

8. Kosenko, O. P. \& Pererva, P. H. (2015). Otsiniuvannia komertsiinoi privablyvostu obektiv intelektualnoi vlasnosti na osnovi tehnolohichnoho vazhelia. In S. V. Kniaz. (Ed.), Torhovelne pidpryiemnytstvo: mekhanizm rozvytku i finansovoi pidtrymky. (pp. 180-195). Lviv: Lvivska politekhnika.

9. Pererva, P. H., \& Tkacheva, N. P. (2011). Sinerhetichnyi efekt benchmarkinhu konkurentnykh perevah. Marketynh $i$ menedzhment innovatsii, 4(1), 55-66.

10. Platonov, V. V. (Ed.). (2008). Intellektualnye aktivy i innovatsii: problemy otsenki, ucheta i upravleniia. Sankt-Peterburg: Izdatelstvo GOU VPO Sankt-Peterburgskii gosudarstvennyi universitet ekonomiki i finansov.

11. Pererva, P. H., \& Poberezhna, N. M. (2012). Vyznachennia efektivnosti vykorystannia vyrobnychoho potentsialu mashynobudivnoho pidpryiemstva. Marketynh i menedzhment innovatsii, 2, 191-198.

12. Pogorelov, N. I., Pererva, P. G., Kolot, A. M., \& Mekhovich, S. A. (2007). Ekonomika i organizatsiia truda. Kharkov: Faktor.

13. Rogova, E. M. (2005). Formirovanie i realizatsiia mekhanizmov tehnologicheskogo transfera. Sankt-Peterburg: Izdatelstvo Sankt-Peterburgskogo gosudarstvennogo universiteta ekonomiki i finansov.

14. Pererva, P. G. (2002). Analiz finansovogo sostoianiia predpriiatiia. Visnyk NTU «KhPI». Tematychnyi vypusk: tekhnichnyi prohress ta efektyvnist vyrobnytstva, 11-2, 118-121.

15. Starostina, A. O. (Ed.). (2009). Marketynh. Kyiv: Znannia.

16. Pererva, P. H., Kosenko, O. P., \& Tkachov, M. M. (2014). Rozvytok metodiv vartisnoi otsinky nematerialnykh aktiviv ta obektiv intelektualnoi vlasnosti. Nauchnye Trudy DonNtu.Seriia ekonomicheskaia, 4, 57-66.

17. Pererva, P. H., \& Tovazhnianskyi, V. L. (2010). Antikryzovyi monitorynh finansovo-ekonomichnykh pokaznykiv roboty mashynobudivnoho pidpryiemstva Ekonomika rozvytku, 2(54), 46-50.

18. Pererva P.G,. Kotsiski, D. (Eds.). (2012). Transfer texnolohii. Kharkov-Mishkolts: NTU «KHPI».

19. Pererva, P. G., Voronovskii, G. K., Mekhovich, S. A., \& Pogorelov, S. I. (Eds.). (2009). Ekonomika i upravlenie innovatsionnoi deiatelnostiu. Kharkov: NTU «KHPI».

Received 11.06.2017

CPererva P. G., Kosenko A. P., Kobielieva T. A., Tkachev M. M., Tkacheva N. P. 